塩基性触媒在用にるエポキシ化合物と綿布の

$$
\text { ウォッシュアンドウウェア加工についで }
$$

\title{
日清紡嘖株式会社美合工場 本 宮 達 也 \\ ON THE WASH AND WEAR FINISH OF COTTON FABRICS BY EPOXY COMPOUNDS IN THE PRESENCE OF ALKALINE CATALYSTS
}

\author{
By Tatsuya Hong $\vec{u}$
}

(Nissin Spinning Co., Ltd., Miai Mill, 45, Irigome, Miai-cho, Okazaki City, Aichi Prefecture, Japan)

The effect of different treatments on cotton fabrics with various epoxides in the presence of alkali catalysts on the W \&W properties and other properties was investigated. The treatments investigated for cotton fabrics impregnated with epoxides were the wet timing ( $T$ ), steaming (S), and curing (C). The epoxides used were diglycidyl ether (I), ethylene glycol diglycidyl ether (II), glycerin diglycidyl ether (III), and diethylene glycol diglycidyl ether (V). Sodium hydroxide was used in most of experiments, in which the catalyst was padded before (B) or after (A) epoxidepadding or the catalyst and the epoxide were padded at the same time from a solution of the mixture (W).

The effectiveness of epoxides to improve wet crease recovery in $B-T$ process was in the order, I $>$ III $>$ II $>$ V.

The effectiveness of the epoxide-treatment under wet conditions for improving wet crease recovery and $W \& W$ properties was in the order $W-T>B-T>W-S>A-T>A-S$. Tear strength decreased as the add-on of the epoxide and the wet crease recovery angle increased. Little increase in dry crease recovery was observed in these treatments.

The effectiveness of the epoxide-treatment under curing conditions on both dry and wet crease recovery angles (dry<wet) was in the order, $W>A>B$.

The most effective catalyst for $T$ precess with I was sodium methoxide, and that for $S$ was sodium peroxide. The effect of the solvent of I was investigated. The improvement of the wet crease recovery obtained by treatments under wet conditions was in the order, water $>$ methanol $>$ ethanol $>$ iso-propanol $>$ acetone $>$ dioxane $>$ tetrahydofuran $>$ benzene.

The effect of combination of the epoxide-treatment and the conventional resin finishing with DMDHEU was also studied. When resin-finished fabric fabrics were followed by the epoxide-treatment under wet conditions, high dry and wet crease recovery angles resistant to washing and higher retention in tear strength was achieved.

The reactions involved in the treatments described above are discussed in connection with the change in the fabric properties as a result of the treatment.

(Received April 16, 1968)

\section{1. 腥言}

低温橋かけ反応をさらに極端にしたものが，いわゆる

*この報交を「エポキシ化合物による綿布のウォッシ ニアンドェフ加工に関する研究(第 3 報) Studies on the wash and wear finish of cotton fabrics epoxy conpounds (Port 3) $ょ ち る$.
湿潤橋かけ反応であり，充分膨潤した状態で橋かけを生 成させることによって湿時しわ回復角が付与される。ジ クロールプロパノール1,2)，エピクロルヒドリン3,4,5) どをもらいた湿潤橋かけ反分に開する研究は比較的行な われているが，水酸化ナトリウムの存在のもとで湿潤状 態で線布とエポキシ化合物を反纯 ${ }^{6,7,8,99}$ させるとき，工 
ポキシ化合物の水溶性と䠅水性炕上る防しわ効果, ある

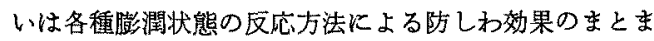
った研究は少ない。またエポキシ化合物を䁗洞状熊で反 応させるとき，水酸化ナトリウム以外の塩基性触媒によ る防しわ効果やエポキシ化合物を各種の溶媒で反応させ る防しわ效果やエポキシ化合物を各種の溶媒で反枕させ たときの防しわ効果についての報告も少ない。

本報では各種の塩基性触媒を用いるエポキシ化合物々 綿布を湿潤括よび乾燥状態で反応させるときの処理効果 や溶媒効果について, ウォシュアンド ウェア加工を 得ることを目的として検郡を加え，若干の知見を得たの で報告する。

\section{2. 試料および実験方法}

\section{$2 \cdot 1$ 試 料}

$2 \cdot 1 \cdot 1$ 綿 布

前報10)で用いた試料 $\mathrm{A}$ 使用した。

$2 \cdot 1 \cdot 2$ エポキシ化合物

前報10)で用いたエポキシドI（ジグリシジルェーテ ル), エポキシドII（エチレングリコールジグリシジルエ ーテル)、エポキシドய(グリセリンジグリシジルエーテ ル)、エポキシドV(ジェチレングリコールジグリシジル エーテル）使用した。

$2 \cdot 1 \cdot 3$ 樹脂加工剤

前報10)で用いた DMDHEU（ジメチロールジヒドロキ シニチレン尿素) を使用した。

\section{$2 \cdot 1 \cdot 4$ 塩基性触媒}

水酸化ナトリウム，過酸化ナトリウム，丸チルアルニ ラート,イソプロピルアミン, テトラメチルアンモニウ ムとドロキシドはいずれる市眅特級試薬を用いた。 $2 \cdot 1 \cdot 5$ 溶 媒 ペンゼン, イソプロピルエーテル, ジオキサン, アセ トン, イソプロピルアルュール，エチルアルコール， メ チルアルコールはいずれる陚薬 1 級を精製して用いた。

\section{$2 \cdot 2$ 処 理}

\section{$2 \cdot 2 \cdot 1$ 処理液の調製}

エポキシド【は水溶液で用い，エポキシド而はポりビ ニールアルコール（市販ポリサイザー 68） $0.5 \mathrm{~g} / 100 \mathrm{~m} l$ を用い、コロイドミルで乳化して用いた。エポキシドII およびVはイソプロピルアルコールと水 $(1: 1)^{11)}$ の混 合溶媒で用いた。エポキシド I，II，正，Vはをそぞれ所 定溓度の処理液と各種の塩基性触媒の所定濃度の処理淮 とを別々に調製して用いた。

$2.2 \cdot 2$ 処理方法

別々に調製したエポキシドと塩基性触媒は，つぎの三 つの方法を用いタイミング処理，スキーミング処理また
はキュアリング処理で反応した。

（1）アルカリ前パディング・タイミング処理

綿布を塩基性触媒の処理液に回浸し，2回絞水（校り 率，70\%) し，つぎにエポキシドの处理液にて2回浸し 2 回絞水（絞り弯，70\%）した。この処理布を外径 4 種 長さ 40 粴の中空ビニール管に巻きとり，これを乾燥し ないよらにポリエキレンシート包んで所定の温度と晆 間で反応した。そのあとソーピングを路こなった。

アルカリ前パディング・スチーミング処理法

（1）同様に処理して中空ビニール管に巻きとりこ れを小型エジャーに入れ $100 \pm 1^{\circ} \mathrm{C}$ て所定の時間反応し た。そのあとソーピングを机こなった。

アルカリ前パディング・キュアリング処理

綿布交塩基性触媒の処理液に 2 回浸し, 2 回絞水（絞 り率，70\%）し，つぎにェポキシドの处理液に2 回浸 し，2回较水（絞り率，70\%）しだ。これを $40^{\circ} \mathrm{C}$ で予 借乾燥し， $140^{\circ} \mathrm{C}$ で 4 分熱处理した。そのあとッーピン グを机こなった。

（2）アルカリ後パディング・タイミング処理

線布をエポキシドの处理液に 2 回漫し， 2 回絞水（较 り率，70\%）したのち，予備乾燥を抏こない，つぎ塩 基性触某の処理に 2 回浸し，2回校水（校り率，70\%) した。この処理布を中空ビニール管に巻きとり(1)法沉 従って反応した。そのあとソーピングを抗をなった。

アルカリ後パディング・ステーミング処理

(2)法同㥞に処理して中空ビニール管に巻きとり，こ れを小型土ジャーに入れ $100 \pm 1^{\circ} \mathrm{C}$ で所定の時間反応し た。そのあとソーピングを就こなった。

アルカリ後パディング・キニアリング処理

綿布夌工ポキシドの処理液に 2 て回 浸 し， 2 回校水 （絞り率，70\%）したのち，予備畭燥を括こない，つぎ に塩基性触媒の処理液に 2 回浸し， 2 回絞水（絞り率, $70 \%$ ) した。これを $40^{\circ} \mathrm{C}$ で予備乾燥し， $140^{\circ} \mathrm{C} て ゙ 4$ 分 熱処理した。そのあとソーピングを打こなった。

(3) 同浴パディング・タイミング処理

綿布をエポキシドと塩基性触媒を混溶した処理液に2 回漫し，2回絞水（絞り率，70\%）した。この処理布を 中空ビニール管に巻きとり（1）法にしたがって反応し た。そのあとンーピングをおこなった。

同浴パディング・スチーミング処理

(3)法同様に処理して中空ビニール管に巻きとり，こ れを小型エジャーに入れ $100 \pm 1^{\circ} \mathrm{C}$ で所定の時間反応し た。そのあとッーピングを报こなった。

同浴パディング・キュアリング処理

綿布をエポキシドと塩基性触媒を混溶した処理夜に2 回浸し，2回较水（絞り率，70\%) した。これを $40^{\circ} \mathrm{C}$ 
で予備乾燥し， $140^{\circ} \mathrm{C} て ゙ 4$ 分熱処理した。冬のあとー ピングを扎こなった。

\section{$2 \cdot 2 \cdot 3$ 樹脂加工法}

DMDHEU $10 \mathrm{~g} / 100 \mathrm{~m} l$ Kホウフッ化西鉛 $0.5 \mathrm{~g} / 100 \mathrm{~m} l$ を加えて処理液とし，これに綿布を 2 回浸し，2回絞水

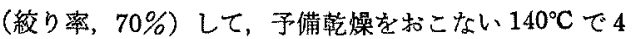
分熱処理した。

\section{$2 \cdot 3$ エポキシ基の定量}

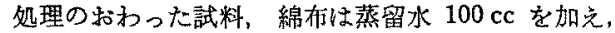
$0.2 \mathrm{~N}$ 塩酸でアルカリを中和し，さらに500 cc ビーカに 之った亜硫酸ナトリウムの飽和溶液 $200 \mathrm{cc}$ 中心常温で 30 分漫した。これに Alizarin yellow-R $(0.1 \mathrm{~g})$ と Xylenecyanol-FF $(0.06 \mathrm{~g})$ を $100 \mathrm{cc}$ の蒸留水に溶解 して調製した指示薬 6 ないし 10 瀜を加克，遊離した水

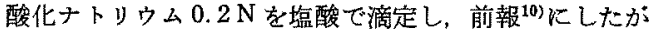
って反応率を求めた。

\section{$2 \cdot 4$ 試験方法}

樹脂付着量, 乾時, 湿時しわ回復角，引裂強度，樹脂 脱落率, ウォシュアンドウェア法（以下W \& W と略 記する)，耐洗濯法はいずれる前埌㣙にしたがった。

$2 \cdot 4 \cdot 1$ 引裂強度保持率

未処理布の引裂強度を $A$, 処理布の引裂強度を $B$ とし 次式によって求めた。

$$
\text { 引裂強度保持率 }(\%)=\frac{B}{A} \times 100
$$

\section{$2 \cdot 4 \cdot 2$ 用欶度}

東洋精機製 Gurley's stiffness tester によった。 $2 \cdot 4 \cdot 3$ 磨耗 (平面) 強度

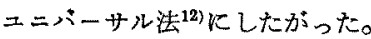

\section{3. 実験結果および考察}

\section{1 アルカリ前バティング・タイミング処理による} 水酸化ナトリウムと各種エポキシトの反応

水酸化ナトリウムの存在のもとで各種エポキシと綿布 をアルカリ前パディング・タイミング処理で反応したと き, 樹脂付着量がしわ回復角と引裂強度に执よぼす影響 を Fig. 1 に示した。

Fig. 1 に示尗5 5 に湿時しわ回復角は樹脂付着量が增 加するほど高くなり，その効果はェポキシドI＞III＞II $>\mathrm{V}$ の順となり，引裂強度と逆の関係になった。このこ 々は水溶性のエポキシドIおよび四は䟱水性のエポキシ ドエおよびVより繊維内に唀して膨潤状態で橋かけ反 応を起すたると思われる。この傾向は分子量の小さいエ ポキシドエは，分子量の大さいエポキシド四よりる大き い。眯水性のエポキシド類も同じよらな傾问を示し，そ の效果は水溶性>眯水性で岕った。䇉時しわ回復角は工

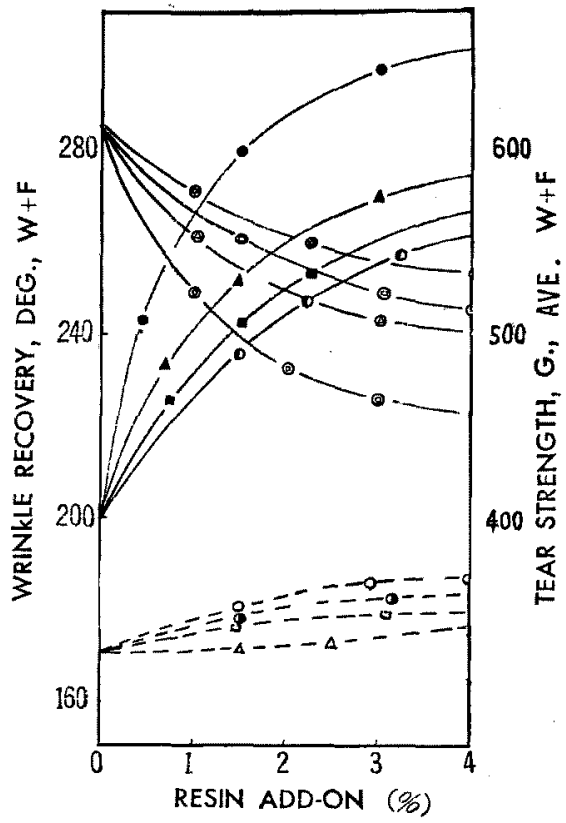

Fig. 1. Relationship between the wrinkle recovery angles, tear strength and resin add-on when cotton fabrics were treated with various Epoxides in the presence of sodium hydroxide. Reaction condition: The cotton fabric was padded with sodium hydroxide $(3 \mathrm{~g} / 100 \mathrm{ml}$, wet pick-up, 70\%), followed by padding with Epoxide I $(20 \mathrm{~g} / 100 \mathrm{ml}$, wet pick-up, $70 \%)$, or with Epoxide II, III, V $(20 \mathrm{~g} / 100 \mathrm{~m} l$ of $1: 1$ mixture of water and isopropyl alcohol, wet pick-up, 70\%). The impregnated fabric was allowed to react by the wet timing process at $25^{\circ} \mathrm{C}$ for desired time.

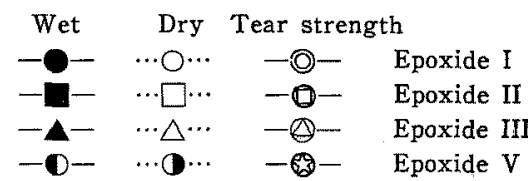

ポキシト I，II，III，V とるに樹脂付着量が增加しててむ ほとんど向上しない。これは膨㵎状態での橋かけ反心に よるためと思われる。

$3 \cdot 2$ アルカリ前パディング・タイミング処理による 水酸化ナトリウムとエポキシト I， III の反応

$3 \cdot 2 \cdot 1$ 反応温度と触媒濃度の関俰

水酸化ナトリウムの存在のもとで綿布をアルカリ前パ ディング・タイミング処理でェボキシドエと反厽したと き, 反応温度と触媒濃度が綿布に就よぼす影響をTable 1 に示し、エポキシド且のそれを Table 2 に示した。 エ决キシドIの場合は，Table 1 に示すように反応温 
Table 1. "Timing" Treatment of Cotton Fabrics with Epoxide I in the Presence of Sodium Hydroxide.

\begin{tabular}{|c|c|c|c|c|c|c|c|c|c|c|}
\hline \multirow{2}{*}{$\begin{array}{l}\text { Tim- } \\
\text { ing } \\
\text { temp. } \\
{ }^{\circ} \mathrm{C}\end{array}$} & \multirow{2}{*}{$\left|\begin{array}{r}\mathrm{NaOH} \\
\mathrm{conc} . \\
\mathrm{g} / 100 \\
\mathrm{~m} l\end{array}\right|$} & \multirow{2}{*}{$\begin{array}{c}\text { Degree } \\
\text { of } \\
\text { reaction } \\
\%\end{array}$} & \multicolumn{2}{|c|}{$\begin{array}{l}\text { Wrinkle recovery } \\
\text { angles }(W+F) \text { deg. }\end{array}$} & \multicolumn{2}{|c|}{$\begin{array}{l}\text { Tearing strength } \\
\text { retained, } \%\end{array}$} & \multirow{2}{*}{$\begin{array}{c}\text { Percentage } \\
\text { of lresin } \\
\text { removed by } \\
\text { laundering } \\
\%\end{array}$} & \multicolumn{2}{|c|}{$W \& W$ rating } & \multirow{2}{*}{$\begin{array}{l}\text { Stiffness } \\
\text { mg }\end{array}$} \\
\hline & & & Dry & Wet & $\begin{array}{c}\text { After } \\
\text { soaping }\end{array}$ & $\begin{array}{l}\text { After 10 } \\
\text { launder- } \\
\text { ings }\end{array}$ & & $\begin{array}{l}\text { After } \\
\text { soping }\end{array}$ & $\begin{array}{l}\text { After } 10 \\
\text { launder- } \\
\text { ings }\end{array}$ & \\
\hline 20 & $\begin{array}{r}1.0 \\
2.0 \\
3.0 \\
5.0 \\
10.0 \\
20.0\end{array}$ & $\begin{array}{c}45.6 \\
70.0 \\
91.7 \\
100 \\
\prime \prime \\
\prime \prime\end{array}$ & $\begin{array}{l}191 \\
206 \\
199 \\
184 \\
210 \\
222\end{array}$ & $\begin{array}{l}275 \\
300 \\
300 \\
291 \\
286 \\
280\end{array}$ & $\begin{array}{l}83 \\
77 \\
73 \\
72 \\
72 \\
70\end{array}$ & $\begin{array}{l}78 \\
73 \\
69 \\
68 \\
66 \\
65\end{array}$ & $\begin{array}{r}9 \\
11 \\
12 \\
13 \\
21 \\
25\end{array}$ & $\begin{array}{l}3 \\
4 \\
4 \\
4 \\
4 \\
4\end{array}$ & $\begin{array}{l}3 \\
4 \\
4 \\
4 \\
3 \\
3\end{array}$ & $\begin{array}{r}3.7 \\
3.8 \\
4.0 \\
5.3 \\
8.5 \\
10.1\end{array}$ \\
\hline 40 & 1.0 & 80.3 & 193 & 298 & 78 & 74 & 10 & 4 & 4 & 3.8 \\
\hline 60 & 1.0 & 100 & 187 & 295 & 76 & 73 & 11 & 4 & 4 & 3.6 \\
\hline 80 & 0.5 & 100 & 180 & 290 & 75 & 71 & 12 & 4 & 4 & 3.9 \\
\hline 100 & $\begin{array}{l}0.5 \\
1.0 \\
3.0 \\
5.0\end{array}$ & $\begin{array}{c}100 \\
" \prime \\
" 1\end{array}$ & $\begin{array}{l}185 \\
190 \\
196 \\
210\end{array}$ & $\begin{array}{l}286 \\
285 \\
283 \\
280\end{array}$ & $\begin{array}{l}74 \\
73 \\
71 \\
69\end{array}$ & $\begin{array}{l}70 \\
69 \\
67 \\
65\end{array}$ & $\begin{array}{l}12 \\
12 \\
18 \\
21\end{array}$ & $\begin{array}{l}4 \\
4 \\
4 \\
4\end{array}$ & $\begin{array}{l}4 \\
4 \\
3 \\
3\end{array}$ & $\begin{array}{l}3.8 \\
4.2 \\
5.8 \\
6.5\end{array}$ \\
\hline \multicolumn{3}{|c|}{ Control fabric } & 177 & 200 & 100 & 100 & 0 . & 1 & 1 & 3.5 \\
\hline
\end{tabular}

Reaction condition: The cotton fabric was padded with sodium hydroxide $(3 \mathrm{~g} / 100 \mathrm{ml}$, wet pick-up, $70 \%)$, followed by padding with Epoxide I $(20 \mathrm{~g} / 100 \mathrm{ml}$, wet pick-up, $70 \%)$. The impregnated fabric was allowed to react by the wet timing process at $20,40,60,80$, or $100^{\circ} \mathrm{C}$ for 6 hours. The treated fabric was soaped with a soap solution $(2 \mathrm{~g} / l$ soda ash and $3 \mathrm{~g} / l$ solid soap) with liquor ratio of $50: 1$ at $60^{\circ} \mathrm{C}$ for 5 minutes.

Table 2. "Timing" Treatment of Cotton Fabrics with Epoxide III in the Presence of Sodium Hydroxide.

\begin{tabular}{|c|c|c|c|c|c|c|c|c|c|c|}
\hline \multirow{2}{*}{$\begin{array}{l}\text { Tim- } \\
\text { ing } \\
\text { temp. } \\
{ }^{\circ} \mathrm{C}\end{array}$} & \multirow{2}{*}{$\left|\begin{array}{c}\mathrm{NaOH} \\
\text { conc. } \\
\mathrm{g} / 100 \\
\mathrm{ml}\end{array}\right|$} & \multirow{2}{*}{$\begin{array}{c}\text { Degree } \\
\text { of } \\
\text { reaction } \\
\%\end{array}$} & \multicolumn{2}{|c|}{$\begin{array}{l}\text { Wrinkle recovery } \\
\text { angles }(W+F) \text { deg. }\end{array}$} & \multicolumn{2}{|c|}{$\begin{array}{l}\text { Tearing strength } \\
\text { retained, } \%\end{array}$} & \multirow{2}{*}{$\begin{array}{c}\text { Percentage } \\
\text { of resin } \\
\text { removed by } \\
\text { laundering } \\
\%\end{array}$} & \multicolumn{2}{|c|}{$W \& W$ rating } & \multirow{2}{*}{$\begin{array}{l}\text { Stiffnes } \\
\text { mg }\end{array}$} \\
\hline & & & Dry & Wet & $\begin{array}{c}\text { After } \\
\text { soaping }\end{array}$ & $\begin{array}{l}\text { After } 10 \\
\text { launder- } \\
\text { ings }\end{array}$ & & $\begin{array}{l}\text { After } \\
\text { soaping }\end{array}$ & $\begin{array}{l}\text { After } 10 \\
\text { launder- } \\
\text { ings }\end{array}$ & \\
\hline 20 & $\begin{array}{r}1.0 \\
2.0 \\
3.0 \\
5.0 \\
10.0 \\
20.0\end{array}$ & $\begin{array}{c}28.7 \\
65.4 \\
90.0 \\
100 \\
\prime \prime \\
\prime \prime\end{array}$ & $\begin{array}{l}159 \\
168 \\
168 \\
166 \\
199 \\
215\end{array}$ & $\begin{array}{l}255 \\
256 \\
280 \\
276 \\
270 \\
265\end{array}$ & $\begin{array}{l}85 \\
81 \\
77 \\
76 \\
78 \\
76\end{array}$ & $\begin{array}{l}80 \\
77 \\
72 \\
71 \\
73 \\
70\end{array}$ & $\begin{array}{r}7 \\
7 \\
9 \\
10 \\
18 \\
23\end{array}$ & $\begin{array}{l}3 \\
3 \\
4 \\
4 \\
4 \\
4\end{array}$ & $\begin{array}{l}3 \\
3 \\
4 \\
4 \\
3 \\
3\end{array}$ & $\begin{array}{r}3.8 \\
4.0 \\
4.2 \\
5.8 \\
9.5 \\
11.5\end{array}$ \\
\hline 40 & 1.0 & 100 & 193 & 295 & 82 & 77 & 8 & 4 & 4 & 4.0 \\
\hline 60 & 1.0 & 100 & 175 & 280 & 81 & 77 & 8 & 4 & 4 & 4.2 \\
\hline 80 & 0.5 & 100 & 167 & 280 & 80 & 75 & 8 & 4 & 4 & 4.3 \\
\hline 100 & $\begin{array}{l}0.5 \\
1.0 \\
3.0 \\
5.0\end{array}$ & $\begin{array}{c}100 \\
" 1 \\
" 1 \\
" 1\end{array}$ & $\begin{array}{l}175 \\
182 \\
191 \\
210\end{array}$ & $\begin{array}{l}270 \\
266 \\
263 \\
263\end{array}$ & $\begin{array}{l}79 \\
77 \\
75 \\
73\end{array}$ & $\begin{array}{l}75 \\
73 \\
71 \\
69\end{array}$ & $\begin{array}{r}8 \\
11 \\
16 \\
22\end{array}$ & $\begin{array}{l}4 \\
4 \\
4 \\
4\end{array}$ & $\begin{array}{l}4 \\
4 \\
3 \\
3\end{array}$ & $\begin{array}{l}4.0 \\
4.5 \\
6.2 \\
7.0\end{array}$ \\
\hline \multicolumn{3}{|c|}{ Control fabric } & 177 & 200 & 100 & 100 & 0 & 1 & 1 & 3.5 \\
\hline
\end{tabular}

Reaction condition: The cotton fabric was padded with sodium hydroxide $(3 \mathrm{~g} / 100 \mathrm{ml}$, wet pick-up, $70 \%$ ), followed by padding with Epoxide III (20 g of Epoxide JII and $0.5 \mathrm{~g}$ of PVA in $100 \mathrm{~m} l$ water). The impregnated fabric was allowed to react by the wet timing process at $20,40,80$ or $100^{\circ} \mathrm{C}$ for 6 hours. The treated fabric was soaped as described in Table 1.

度 $20^{\circ} \mathrm{C}$ のとき触媒濃度 $2.0 \sim 3.0 \mathrm{~g} / 100 \mathrm{ml}$ で約 300 度 の湿時しわ回復角が得られ，W \&W は洗たく前和よび 洗たく 10 回後でともに 4 であった。400 $の$ $1.0 \mathrm{~g} /$ $100 \mathrm{~m} l$ で約 298 度の湿時しわ回復角が得られ，60
とき $1.0 \mathrm{~g} / 100 \mathrm{ml}$ で約 295 度, $80^{\circ} \mathrm{C}$ のとき $0.5 \mathrm{~g} / 100$ $\mathrm{m} l$ で約 290 度, $100^{\circ} \mathrm{C}$ のとき $0.5 \mathrm{~g} / 100 \mathrm{ml}$ で約 286 度 のそれそれの湿時しわ回復角が得られ，W \&W は洗た く前和よび洗たく 10 回後いむいずれの場合も4であっ 
た。引裂強度保持率は湿時しわ回復角が高いほどまた反 応温度が高くなるほど低下した。

エポキシドாの㫷合は, Table 2 に示すように反応温 度 $20^{\circ} \mathrm{C}$ のとき触媒濃度 $3.0 \mathrm{~g} / 100 \mathrm{~m} l$ で湿時しわ回復 角㤝約 280 度の值が得られ，W \& W は洗たく前执よび 洗たく 10 回後でともに 4 であった。 $40^{\circ} \mathrm{C}$ のとき 1.0 $\mathrm{g} / 100 \mathrm{ml}$ で約 295 度, $60^{\circ} \mathrm{C}$ のとき $1.0 \mathrm{~g} / 100 \mathrm{ml}$ で約 280 度, $80^{\circ} \mathrm{C}$ のとき $0.5 \mathrm{~g} / 100 \mathrm{ml}$ で約 280 度, $100^{\circ} \mathrm{C}$ のとき $0.5 \mathrm{~g} / 100 \mathrm{ml}$ で約 270 度のそれぞれの湿時しわ 回復角が得られ，W \& W は洗たん前および洗たく 10 回後ともにいずれの場合も4であった。引敉強度保持率 は湿時しわ回復角が高いほどまた反応温度が高くなるは ど低下した。

エポキシドI，吕ともに各反応温度で触媒䟴度がすく なくても，また多くても充分な湿時しわ回復角が得られ なかった。これは触㷊濃度がすくないと途中まで橋かけ 反心にあらかるが，それ以上では加水分解を起すためと 思われる。また触媒濃度が多くなるほど樹脂付着量は増

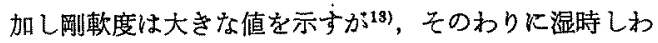
回復角は大きくならなかった。これは触媒濃度が多いと 途中まで橋かけ反応にあづかるが，それ以上ではポリマ 一を形成するが，特にエポキシド四は主鎖中に OH 基を 含さたる三次元構造を形式して綿布が硬くなり剛軟度は 大きな值を示するのと考えられる。このことは樹脂脱落 率の大きいことでもかかる。したがって触媒濃度が高け れ坆主鎖中に $\mathrm{OH}$ 基家含じエポキシドを用いた汪らが， 硬くなることを意味し，擬麻加工に応用できる。またエ ポキシドIや林を用いた場合，反心温度と触媒濃度によ って, 湿時しわ回復角が相違することを意味し，引踤強
度保持率の低下が少ない高い湿時しわ回復角を得るため にはその反沈温度にふさわしい触禁濃度を用いて効率よ く祜かけ反応をさせ，しかもでさるだけ少量の墧かけを 效果的な場所につくら世ることが必要であることがわか る。

\section{$3 \cdot 2 \cdot 2$ スキーミング処理と触媒濃度の関係}

水酸化ナトリウムの存在のもとでェポキシドエおよび III 綿布をアルカリ前パディング・ステーミング処理で 反応したとさ，樹脂付着量がしか回復角と引裂強度にお よ妵す影響を Fig.2に示し，触媒濃度が綿布におよぼす 影暫を Table 3 に示した。

樹脂加エにスチーミング処理を利用する方法について はJ.T.Marsh ら ${ }^{14)}$ おざ小西ら ${ }^{15}$ によっておこなわれ 加工布のしわ回復性と引裂強度, 磨耗強度の低下が改善 されることを報告している。また T.Franics ら 酸化ナトリウムの存在のるとが綿布をエピクロルヒドリ ン蒸気之反応さ媓特間に湿時しわ回復角を改善するこ とを報告している。

著者らは引裂強度の低下改善を行ない,ささらに湿時し わ回復角の向上を短時間に得る目的で，水酸化ナトリウ ムの存在のもとで綿布をアルカリ前パディング・スチー ミング处理で反応したときの綿布の性質について検討を 加齐た。

Fig.2-1 に示すように樹脂付着量が $3 \sim 4 \%$ 付近で, 急激に湿時しわ回復角は向上したが, それ以上の付着量 では漸增した。また樹脂加工（DMDHEUを使用）を行 なった綿布に対しエポキシド処理を行なったときは Fig. 2-2 に示すように樹脂付着量が $6 \sim 7 \%$ 付近で, 急激に 湿時しわ回復角は向上したが，それ以上の付着量では激

Table 3. "Steaming" Treatment of Cotton Fabrics with Epoxide I, III in the Presence of Various Amounts of Sodium Hydroxide.

\begin{tabular}{|c|c|c|c|c|c|c|c|c|c|c|}
\hline \multirow{3}{*}{$\begin{array}{l}\text { Sodium } \\
\text { hydrox- } \\
\text { ide conc. } \\
\mathrm{g} / 100 \mathrm{~m} l\end{array}$} & \multicolumn{5}{|c|}{ Epoxide I } & \multicolumn{5}{|c|}{ Epoxide III } \\
\hline & \multirow{2}{*}{$\begin{array}{c}\text { Resin } \\
\text { add-on } \\
\%\end{array}$} & \multicolumn{2}{|c|}{$\begin{array}{l}\text { Wrinkle recovery } \\
\text { ang. }(W+F) \text { deg. }\end{array}$} & \multirow{2}{*}{$\begin{array}{c}\text { Tearing } \\
\text { strength } \\
\text { retaind, } \\
\%\end{array}$} & \multirow{2}{*}{$\begin{array}{c}\text { Strength } \\
\text { of abrasion } \\
\text { plane } \\
\text { cycle }\end{array}$} & \multirow{2}{*}{$\begin{array}{c}\text { Resin } \\
\text { add-on } \\
\%\end{array}$} & \multicolumn{2}{|c|}{$\begin{array}{l}\text { Wrinkle recovery } \\
\text { ang. }(W+F) \text { deg. }\end{array}$} & \multirow{2}{*}{$\begin{array}{c}\text { Tearing } \\
\text { strength } \\
\text { reta ind, } \\
\%\end{array}$} & \multirow{2}{*}{$\begin{array}{l}\text { Strength } \\
\text { of abrasior } \\
\text { plane } \\
\text { cycle }\end{array}$} \\
\hline & & Dry & Wet & & & & Dry & Wet & & \\
\hline 0 & 0 & 177 & 200 & 100 & 233 & 0 & 177 & 200 & 100 & 233 \\
\hline 0.5 & 1.1 & 185 & 245 & 80 & 206 & 0.5 & 180 & 240 & 88 & 220 \\
\hline 1.0 & 2.3 & 188 & 283 & 77 & 220 & 1.7 & 185 & 276 & 85 & 228 \\
\hline 2.0 & 2.8 & 190 & 291 & 71 & 235 & 2.3 & 199 & 280 & 82 & 236 \\
\hline 3.0 & 3.3 & 190 & 290 & 70 & 240 & 2.6 & 200 & 285 & 79 & 249 \\
\hline 5.0 & 3.1 & 205 & 285 & 72 & 265 & 3.4 & 205 & 275 & 77 & 263 \\
\hline 10.0 & 4.4 & 208 & 283 & 71 & 275 & 3,7 & 218 & 270 & 76 & 282 \\
\hline
\end{tabular}

Reaction condition: The cotton fabric was padded with various concentration of sodium hydroxide (wet pick-up, $70 \%$ ), followed by padding with $30 \mathrm{~g} / 100 \mathrm{ml}$ aqueous solution of Epoxide 1 , or an emulsion Epoxide III ( $30 \mathrm{~g}$ of Epoxide III and $0.5 \mathrm{~g}$ of PVA in $100 \mathrm{~m} l$ water). The impregnated fabric was treated by steaming at $100^{\circ} \mathrm{C}$ for $3 \mathrm{~min}$. The treated fabric was soaped as described in Table 1. 


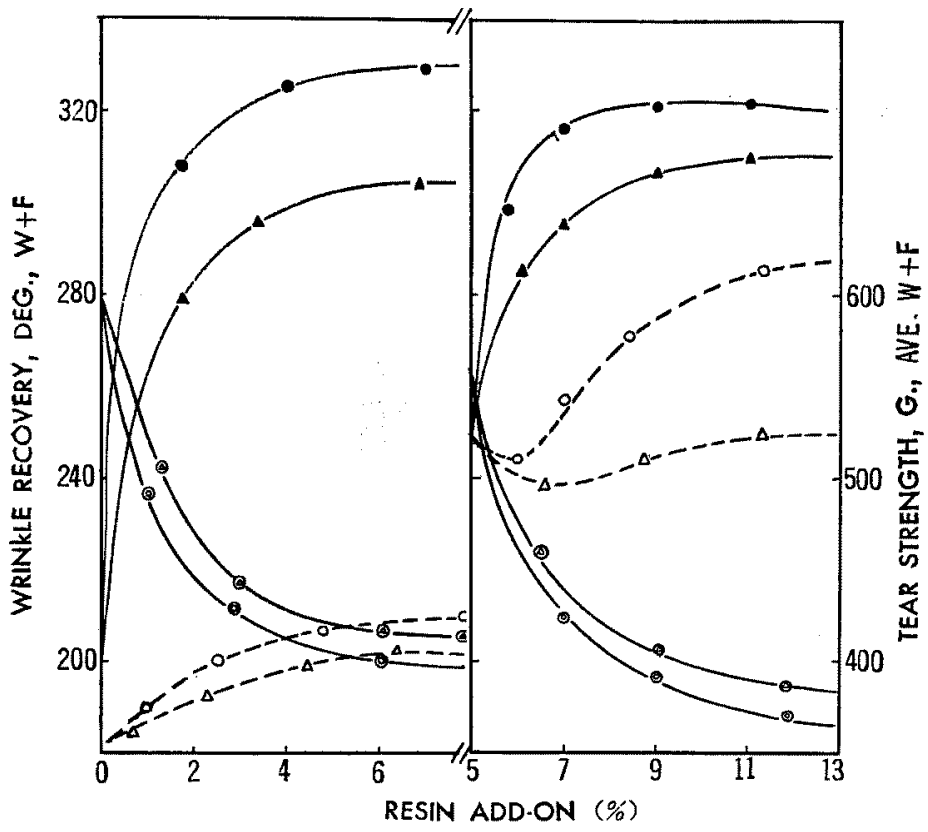

Fig. 2-1. Without resin finish

Fig. 2-2. With resin finish

Fig. 2. The effects of resin add-on on the wrinkle recovery angles and tear strength when cotton fabrics were treated with Epoxide I or III by the "steaming" treatment in the presence of sodium hydroxide.

Reaction condition: The cotton fabric was padded with sodium hydroxide $(3 \mathrm{~g} / 100 \mathrm{~m} l$, wet pick-up, $70 \%)$, followed by padding with Epoxide I $(20 \mathrm{~g} / 100 \mathrm{ml}$ wet pick-up, $70 \%)$, or with Epoxide III $(20 \mathrm{~g} / 100 \mathrm{ml}$, of $1: 1$ mixture of water and isopropyl alcohol, wet pick-up, 70\%). The impregnated fabric was treated by steaming of $100^{\circ} \mathrm{C}$ for desired time.

$\begin{array}{cccl}\text { Wet } & \text { Dry Tear strength } & \\ -\mathbf{-} & \cdots \bigcirc \cdots & -\mathrm{O}- & \text { Epoxide I } \\ -\mathbf{A}- & \cdots \triangle \cdots & -\otimes- & \text { Epoxide III }\end{array}$

グ・スチーミング処理で反応した とき，水酸化ナトリウムの少ない 場合，Table 3 に示与上う火充分 な湿時しわ回復角は得られない。 また水酸化ナトリウムの多い場合 は，途中をで橋かけ反応が起るが それ以上では樹脂付着量が多くな って西湿時しわ回復角は得られな いが，これはボりマ一形成による ものと考光らる。この結果はア ルカリ前パディング・タイミング 処理の場合 (Table 1, Table 2) と注活同様な傾向である。しかし 乾時しわ回復角は水酸化ナトリウ ムの濃度に関係なくほとんど向上 Lない。

また豖酸化ナトリウムの存在の るとでエポキシドIおよび四と綿 布をアルカリ前パディング・スキ ーミング処理すれば，エポキシド I括よび而のパッドードライーキ ェ.フ好理に上る上り同一樹脂付着 量 ${ }^{10)}$ に対する引裂強度の低下が少 ない。これは橋かけ反応侁立っ てスチーミング (蒸熱) のため紻 維が充分膨潤し，内部ポりマーが 形成されるので織維構造の崩褧を 防ぐとともに パッドードライー キニア処理の場合にみられるミク ロフィプリル表面の過度の橋かけ 化を，避けることができるためと 思われる。またエボキシドエおよ
增した。反応温度 $100^{\circ} \mathrm{C}$ のスチーミング処理の場合には 少ない触媒濃度で短時間に充分橋かけ反応が起り，した がって高い湿時しわ回復角が得られるるのと考方られ る。このことはスチーミング処理すれば充分膨潤した緎 維の内部で橋かけ化が進み，しかも少量の橋かけが效果 的な場所にできることを意味している。

䩚時しわ回復角はエポキシド処理の場合 (Fig. 2-1) 樹脂付着量が $3 \sim 4 \%$ 付近でもはとんど向上しない。 た樹脂加工とェポキシド処理を併用した場合（Fig. 2-2） の乾時しわ回復角は樹脂加工が併用されるため向上する が，樹脂付着量 6〜7\% 付近で一時低下の傾向が双られ た。これは樹脂加工で付与された余分な樹脂が水酸化ナ トリウムで取除かれるためと思われる。

エポキシドI拉よび亚と綿布をアルカり前パディン
び而ともに触媒濃度の变化による処理布の，磨耗強度は Table 3 に示寸上らに一定の值を示し大きな变化は名ら れなかっだ

\section{$3 \cdot 3$ 水酸化ナトリウムとエポキシドI をタイミンク}

処理で反応したときの防しわ効果

水酸化ナトリウムの存在のもとでエポキシドI と綿布 をアルカリ前パディング,アルカリ後パディング，また は同浴パディングを行ない，それぞれタイミング、スチ ーミングまたはキ土アリング処理で反応したときの防 しか效果を Table 4 に示し、エポキシドIの濃度変化

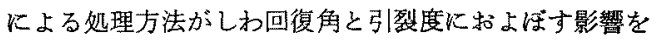
Fig. 3 に示した。

水酸化ナトリウムの存在のもとでエポキシ化合物と綿 布を㚭理する従来の反応 $6,7,8,9)$ では，綿布を水酸化ナト 


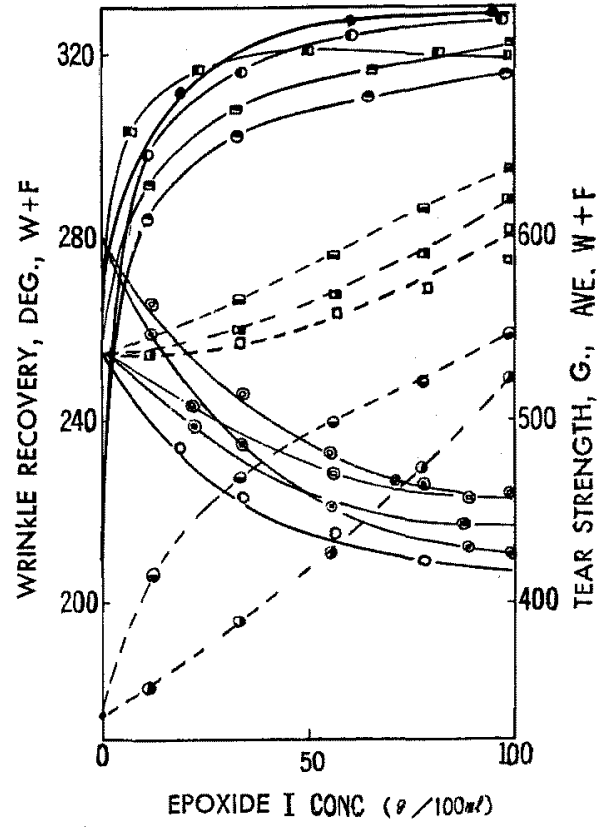

Fig. 3. Relationship between the wrinkle recovery angles, tear strength and concentration of Epoxides I when cotton fabrics were treated with Epoxide I by various techniques in the presence of sodium hydrxide.

Reaction condition: The cotton fabric was padded by B-T, A-T, R-B-T or B-T-R, R-A-T techniques. B-T: The cotton fabric was padded with sodium hydroxide $(3 \mathrm{~g} / 100 \mathrm{ml}$, wet pick-up, $70 \%)$, followed by padding with Epoxide I (various concentrations, wet pick-up, 70\%). The impregnated fabric was allowed to react by the wet timing process at $25^{\circ} \mathrm{C}$ for $6 \mathrm{hr}$.

A-T : The cotton fabric was padded with Epoxide I (various concentrations, wet pick-up, $70 \%$ ) followed by padding sodium hydroxide $(3 \mathrm{~g} / 100 \mathrm{~m} l$, wet pick-up, 70\%). The impregnated fabric was allowed to react by the wet timing process at 25 ${ }^{\circ} \mathrm{C}$ for $6 \mathrm{hr}$.

R-B-T : The cotton fabric was treatedwith DMDHEU by the conventional pad-dry-cure technique(DMDHEU $10 \mathrm{~g}$ and $\mathrm{Zn}\left(\mathrm{BF}_{4}\right)_{2} 0.5 \mathrm{~g}$ in $100 \mathrm{ml}$ of water, wet picp-up, $70 \%$ : pre-dried at $60^{\circ} \mathrm{C}$ for $10 \mathrm{~min}$. and cured at $140^{\circ} \mathrm{C}$ for $4 \mathrm{~min}$.). The resin-finished fabric was treated with Epoxide I as follows: The fabric was padded with sodium hydroxide $(3 \mathrm{~g} / 100$ $\mathrm{ml}$, wet pick-up, $70 \%$ ), followed by padding with Epoxide I (various concentration, wet pickup, 70\%). The impregnated fabric was allowed to react by the wet timing process at $25^{\circ} \mathrm{C}$ for $6 \mathrm{hr}$ B-T-R : The cotton fabric was padded with sodium hydroxide $(3 \mathrm{~g} / 100 \mathrm{ml}$, wet pick-up, $70 \%)$, followed by padding with Epoxide I (various concentration, wet pick-up, 70\%). The impregnated fabric was allowed to react by the wet timing process at $25^{\circ} \mathrm{C}$ for $6 \mathrm{hr}$. The epoxide-treated fabric was treated with DMDHEU by the conventional pad-dry-cure technique (DMDHEU $10 \mathrm{~g}$ and $\mathrm{Zn}\left(\mathrm{BF}_{4}\right)_{2} 0.5 \mathrm{~g}$ in $100 \mathrm{ml}$ of water, wet pick-up, $70 \%$ : pre-dried at $60^{\circ} \mathrm{C}$ for $10 \mathrm{~min}$. cured at $140^{\circ} \mathrm{C}$ for $4 \mathrm{~min}$.).

R-A-T: The cotton fabric was treated with DMDHEU by the conventional pad-dry-cure technique (DMDHEU $10 \mathrm{~g}$ and $\mathrm{Zn}\left(\mathrm{BF}_{4}\right)_{2} 0.5 \mathrm{~g}$ in $100 \mathrm{ml}$ of water, wet pick-up, $70 \%$ : pre-dried at $60^{\circ} \mathrm{C}$ for $10 \mathrm{~min}$. and cured at $140^{\circ} \mathrm{C}$ for $4 \mathrm{~min}$.). The resinfinished fabric was treated with Epoxide T (various concentration, wet pick-up, 70\%), followed by padding with sodium hydroxide $(3 \mathrm{~g} / 100 \mathrm{ml}$, wet pick-up, 70\%). The impregnated fabric was allowed to react by the wet timing process at $25^{\circ} \mathrm{C}$ for $6 \mathrm{hr}$.

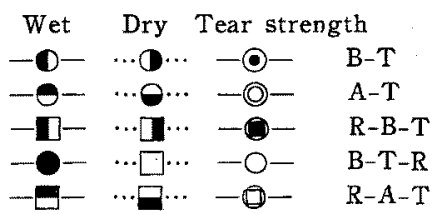

リウムで処理した後に、エポキシ化合物で反心させるい わゆるアルカリ前パディング・タイミング妈理がとられ ている。この方法は繊維のもつ-OH 基を水酸化ナトリ ウムでーONaKかえ，-ONa とエポ手シ基を反応させて橋 かけ反応を起して湿時しわ回復角を向上させる方法であ るが㚐分橋かけ反応が進行して瀻維構造の崩壤が起り， 引裂強度の低下が大きかった。

したがってアルカリ前パディング・タイミング処理を 逆にして，綿布をエポキシ化合物で処理した後に，水酸 化ナトリウムで反応させるアルカリ後パディング・タイ ミング処理を行えば，湿時の橋かけ反応が進行するが， エポキシ化合物による内部ポリマーが形成されるので織 維構造の崩壊を防ぐことがでさるのではないる考完られ る。また水酸化ナトリウムと土ポキシドを混溶すれば当 然反応が進行し，加水分解支るいはポりマーが形成され るがら，同浴パディング・タイミング処理で反応すれ 代，エポキシ化合物をあらかじがリマーを形成させて お走，鎖長の長くなった化合物で処理すると同じような 防しわ効果が得られると考えられる。このときタイミン グ処理を用いれば，維絨の崩壊を防ぐだ引裂強度の低 下の少ない，しかも湿時しわ回復後が短時間に得られる ことが考えられる。

以上の考えは，いずれも湿潤状態での反心について考 
Table 4. The Effects of Laundering the Various Treated of Cotton Fabrics with Epoxide I in the Presence of Sodium Hydroxide.

\begin{tabular}{|c|c|c|c|c|c|c|c|c|c|c|c|c|}
\hline \multirow{3}{*}{ Techniques } & \multirow{3}{*}{\begin{tabular}{|c|}
$\begin{array}{c}\text { Resin } \\
\text { add-on } \\
\%\end{array}$ \\
$\begin{array}{c}\text { After } \\
\text { soaping }\end{array}$ \\
\end{tabular}} & \multirow{3}{*}{$\begin{array}{c}\text { Resin } \\
\text { remov- } \\
\text { ed by } \\
40 \\
\text { launder } \\
\text { ing } \\
\%\end{array}$} & \multicolumn{4}{|c|}{$\begin{array}{l}\text { Wrinkle recovery } \\
\text { ang. }(W+F) \text { deg. }\end{array}$} & \multicolumn{2}{|c|}{$\begin{array}{l}\text { Tearing stren- } \\
\text { gth retaind, } \%\end{array}$} & \multicolumn{2}{|c|}{ W \& $W$ rating } & \multicolumn{2}{|c|}{ Stiffness, $\mathrm{mg}$} \\
\hline & & & \multicolumn{2}{|c|}{ Dry } & \multicolumn{2}{|c|}{ Wet } & \multirow[b]{2}{*}{$\begin{array}{l}\text { After } \\
\text { soaping }\end{array}$} & \multirow{2}{*}{$\begin{array}{c}\text { After } \\
40 \\
\text { laun- } \\
\text { derings }\end{array}$} & \multirow[b]{2}{*}{$\begin{array}{l}\text { After } \\
\text { soaping }\end{array}$} & \multirow{2}{*}{$\begin{array}{c}\text { After } \\
40 \\
\text { laun- } \\
\text { derings }\end{array}$} & \multirow{2}{*}{$\begin{array}{l}\text { After } \\
\text { soaping }\end{array}$} & \multirow{2}{*}{$\begin{array}{c}\text { After } \\
40 \\
\text { laun- } \\
\text { derings }\end{array}$} \\
\hline & & & $\begin{array}{l}\text { After } \\
\text { soaping }\end{array}$ & $\begin{array}{l}\text { After } 40 \\
\text { laun- } \\
\text { derings }\end{array}$ & $\begin{array}{l}\text { After } \\
\text { Soaping }\end{array}$ & $\begin{array}{l}\text { After } 40 \\
\text { laun- } \\
\text { derings }\end{array}$ & & & & & & \\
\hline$B * 1_{-} T^{* 2}$ treatment*a & 4.3 & 36.2 & 182 & 180 & 298 & 285 & 74 & 68 & 4 & 3 & 3.5 & 3.0 \\
\hline$A^{* 8_{-}} \mathrm{T}$ treatment*b & 3.3 & 40.5 & 185 & 183 & 280 & 270 & 76 & 72 & 4 & 3 & 3.9 & 3.5 \\
\hline$A-S^{* 4}$ treatment*e & 3.0 & 42.3 & 190 & 186 & 277 & 258 & 80 & 76 & 3 & 2 & 3.2 & 3. 0 \\
\hline$W^{* b_{-}} \mathrm{T}$ treatment $* \mathrm{~d}$ & 4.4 & 33.7 & 180 & 176 & 310 & 287 & 73 & 70 & 5 & 4 & 4.3 & 3.9 \\
\hline W-S treatment* & 3.8 & 39.0 & 187 & 180 & 291 & 282 & 75 & 65 & 4 & 3 & 4.2 & 3.8 \\
\hline$R^{* f}$ & 4.0 & 45.7 & 256 & 235 & 248 & 231 & 73 & 68 & 3 & 2 & 3.9 & 2.7 \\
\hline R-B-T treatment*g & 7.4 & 38.3 & 267 & 254 & 300 & 290 & 68 & 58 & 5 & 4 & 4.3 & 3.9 \\
\hline $\mathrm{B}-\mathrm{T}-\mathrm{R}$ treatment ${ }^{* \mathrm{~h}}$ & 8.1 & 40.2 & 255 & 237 & 306 & 278 & 62 & 51 & 5 & 4 & 5.8 & 4.3 \\
\hline $\mathrm{B}-\mathrm{C}^{* 6}$ treatment*1 & 2.8 & 50.2 & 210 & 200 & 245 & 225 & 80 & 73 & 3 & 2 & 4.0 & 3.2 \\
\hline A-C treatment*j & 3.4 & 47.0 & 236 & 208 & 246 & 238 & 78 & 72 & 3 & 2 & 4.2 & 3.0 \\
\hline $\mathrm{W}-\mathrm{C}$ treatment*k & 3.3 & 54.5 & 224 & 210 & 242 & 231 & 79 & 71 & 3 & 2 & 4.8 & 3.5 \\
\hline $\mathrm{A}-\mathrm{C}-\mathrm{T}$ treatment $* \mathrm{l}$ & 4.0 & 43.0 & 216 & 208 & 268 & 252 & 76 & 73 & 4 & 2 & 4.4 & 3.8 \\
\hline Control fabric & 0 & & 170 & 180 & 200 & 210 & 100 & 100 & 1 & & 3.0 & 2.6 \\
\hline
\end{tabular}

*1, *3; The catalyst was padded before (B) or after (A) Epxide-padding

*2; Wet timing $(T)$

$*_{4}$; Steaming (S)

*5; The catalyst and the eppoxide were padded at the same time from a solution of the mixture (W).

*6; Curing (C)

Reaction condition : Sample A was treated under various condition

* The cotton fabric was padded with sodium hydroxide $(3 \mathrm{~g} / 100 \mathrm{ml}$, wet pick-up, $70 \%)$, followed by padding with Epoxide I $(30 \mathrm{~g} / 100 \mathrm{ml}$, wet pick-up, $70 \%)$. The impregnated fabric was allowed to react by the wet timing process at $25^{\circ} \mathrm{C}$ for $10 \mathrm{hr}$.

*b The cotton fabric was padded with Epoxide I $(30 \mathrm{~g} / 100 \mathrm{~m} l$, wet pick-up, $70 \%)$ followed by padding with sodium hydroxide $(3 \mathrm{~g} / 100 \mathrm{ml}$, wet pick-up, $70 \%)$. The impregnated fabric was allowed to react by the wet timing process at $25^{\circ} \mathrm{C}$ for $10 \mathrm{hr}$.

*e The cotton fabric was padded with Epoxide I $(30 \mathrm{~g} / 100 \mathrm{ml}$, wet pick-up, $70 \%)$ followed by padding with sodium hydroxide $(3 \mathrm{~g} / 100 \mathrm{ml}$, wet pick-up, $70 \%)$. The impregnated fabric was treated by steaming at $100^{\circ} \mathrm{C}$ for $3 \mathrm{~min}$.

*d The cotton fabric was padded with sodium hydroxide and Epoxide I from a mixture ( $\mathrm{NaOH} 3 \mathrm{~g}$ and Epoxide $\mathrm{I} 30 \mathrm{~g}$ in $100 \mathrm{ml}$ water, wet pick-up, $70 \%$ ). The impregnated fabric was allowed to react by the wet timing process at $25^{\circ} \mathrm{C}$ for $10 \mathrm{hr}$.

* The cotton fabric was padded with sodium hydroxide and Epoxide I from mixture $(\mathrm{NaOH} 3 \mathrm{~g}$ and Epoxide $130 \mathrm{~g}$ in $100 \mathrm{~m} l$ water, wet pick-up, $70 \%$ ). The impregnated fabric was treated by steaming at $100^{\circ} \mathrm{C}$ for $3 \mathrm{~min}$.

* The fabric was treated with DMDHEU by the conventional pad-dry-cure technique (DMDHEU $10 \mathrm{~g}$ and $\mathrm{Zn}\left(\mathrm{BF}_{4}\right)_{2} 0.5 \mathrm{~g}$ in $100 \mathrm{ml}$ of water, wet pick-up, $70 \%$ : pre-dried at $60^{\circ} \mathrm{C}$ for $10 \mathrm{~min}$. and cured at $140^{\circ} \mathrm{C}$ for $4 \mathrm{~min}$.).

* The cotton fabric was treated with DMDHEU by the conventional pad-cure technique (DMDHEU $10 \mathrm{~g}$ and $\mathrm{Zn}\left(\mathrm{BF}_{4}\right)_{2} 0.5 \mathrm{~g}$ in $100 \mathrm{ml}$ of water, wet pick-up, $70 \%:$ pre-dried at $60^{\circ} \mathrm{C}$ for $10 \mathrm{~min}$. and cured at 140 ${ }^{\circ} \mathrm{C}$ for 4 min.). The resin-finished fabric was treated with Epoxide $I$ as follows: The fabric was padded with sodium hydroxide $(3 \mathrm{~g} / 100 \mathrm{~m} l$, wet pick-up, $70 \%)$, followed by padding with Epoxide $\mathrm{I}(30 \mathrm{~g} / 100 \mathrm{~m} l$, wet pick-up, 70\%). The impregnated fabric was allowed to react by the wet timing process at $25^{\circ} \mathrm{C}$ for $10 \mathrm{hr}$.

*h The cotton fabric was padded with sodium hydroxide $(3 \mathrm{~g} / 100 \mathrm{ml}$, wet pick-up, $70 \%)$, followed by padding with Epoxide I $(30 \mathrm{~g} / 100 \mathrm{ml}$, wet pick-up, $70 \%)$. The impregnated fabric was allowed to react by the wet timing process at $25^{\circ} \mathrm{C}$ for $10 \mathrm{hr}$. The epoxide-treated fabric was treated with DMDHEU by 
the conventional pad-dry-cure technique (DMDHEU $10 \mathrm{~g}$ and $\mathrm{Zn}_{\mathrm{n}}\left(\mathrm{BF}_{4}\right)_{2} 0.5 \mathrm{~g}$ in $100 \mathrm{ml}$ of water, wet pick-up, $70 \%$ : pre-dried at $60^{\circ} \mathrm{C}$ for $10 \mathrm{~min}$. and cured at $140^{\circ} \mathrm{C}$ for $4 \mathrm{~min}$.).

*i The cotton fabric was padded with sodium hydroxide $(3 \mathrm{~g} / 100 \mathrm{ml}$, wet kick-up, $70 \%)$, followed by padding with Epoxide I $(30 \mathrm{~g} / 100 \mathrm{ml}$, wet pick-up, $70 \%)$. The impregnated fabric was treated by curing at $140^{\circ} \mathrm{C}$ for $4 \mathrm{~min}$.

*j The cotton fabric was padded with Epoxide I $(30 \mathrm{~g} / 100 \mathrm{ml}$, wet pick-up, $70 \%)$, followed by padding with sodium hydroxide $(3 \mathrm{~g} / 100 \mathrm{ml}$, wet pick-up, $70 \%)$. The impregnated fabric was treated by curing at $140^{\circ} \mathrm{C}$ for $4 \mathrm{~min}$.

* $k$ The cotton fabric was padded with sodium hydroxide and Epoxide I from a mixture $(\mathrm{NaOH} 3 \mathrm{~g}$ and Epoxide I $30 \mathrm{~g}$ in $100 \mathrm{ml}$ water, wet pick-up, 70\%). The impregnated fabric was treated by curing at $140^{\circ} \mathrm{C}$ for $4 \mathrm{~min}$.

*1 The cotton fabric was padded with Epoxide I $(30 \mathrm{~g} / 100 \mathrm{ml}$, wet pick-up, $70 \%)$, followed by padding with sodium hydroxide $(3 \mathrm{~g} / 100 \mathrm{ml}$, wet pick-up, $70 \%)$. The impregnated fabric was treated by curing at $140^{\circ} \mathrm{C}$ for $4 \mathrm{~min}$. The treated fabric was padded with sodium hydroxide $(1 \mathrm{~g} / 100 \mathrm{ml}$, wet pick-up, 70 $\%$ ). The impregnated fabric was allowed to react by the wet timing. process at $25^{\circ} \mathrm{C}$ for $10 \mathrm{hr}$.

The treated sample was soaped as described in Table 1.

えたが，乾㰾状態での反応，すなわちパッドードライー キュア法で処理すれば雗基性触媒の存在のもとであって 当当然非膨㵎状態での橋かけ反応が起るわけで乾時しわ 回復角の向上が期待できる。また湿時しわ回復角は多く を望めないが，繊維の崩壊は少ないものと考光ることが でる。

以上の考えにもとついて険討した結果は Table 4 に示

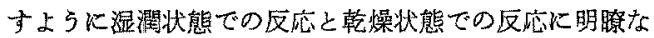
垟が多た。

先づ湿潤状態での反応ではアルカリ前パディング・タ イミング処瑟，アルカリ後パディング・タイミング処理 およびスキーミング処理，同浴パディング・タイミング 処理およびスチーミング処理のいずれの昜合でも湿時〉 乾時のしわ回復角を示した。樹脂付着量, 湿しわ回復角 招よび W \& W の效果は同浴パディング・タイミング処 理〉アルカリ前パディング・タイミング処理〉同浴パデ ヘング・スチーミング処理〉アルカリ後パディング・タ イミング処理〉アルカリ後パディング・スキーミング処 理の順となったが，乾時しわ回復解はほとんどを得られ なかった。引裂強度保持率は樹脂付着量湿時しか回復角 扣よびW \&W の效果の大きいぼかさく，逆の周係を 示した。また剛柔度は湿時しわ回復角拈よびW \&Wの 效果が大きい忹どそれらの閏に大きな善はないが，やや 大きい值を示した。これは妩理布が硬い風合になること を意味する。これらの結果は洗たく 10 回後でもはは同 しょうな傾向を示した。

また湿潤状態に打けるそれ艺れの処理の違いによる效 果は次の上5になった。すなわちアルカリ前パディン グ・ダイミング姏理とアルカリ後パディング・ダミン グ処理を比較すると湿時しわ回復角はアルカリ前パディ ング・タイミング処理のはらか゚、アルカリ後パディン グ・タイミング処理上り高く得られたが，引裂強度保持
率はアルカリ後バディング・タイミング処理のはらがア ルカリ前パディング・タイミング処理より大をくこの ことは緘維をアルカリせルロースにしてエポキシ基と反 応させたはらが，橋かけ反㐫が充分起ることを示し，ア ルカリ後パディング・タイミング処理はエポキシドを瀻 維の内部にポリマーを形成させるため，橋が反応が充 分起らず，したがって湿時しわ回復角は充分付与されな いが，緎維擭造の崩壊を防ぐため引裂強度保持率が大き いるのと侾えられる。

アルカリ後パディンダ・スチーミンダ処理はアルカリ 後ガディング・タイミング观理よりスチーミング(蒸熱) 処理のため織維が急激に䁗潤し，湿特の橋かけが急速に 進行するため，内部ポリマーが形成され，タイミング処

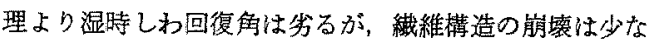
く、したがってスチーミング処理の引裂強度保持率はタ イミング処理より大きいものと考えられる。

次に同浴パディング・タイミング処理の湿時しわ回復 角のほらがアルカリ前パディング・タイミング処理より 大きい。水酸化ナトりウムとエポキシドを混合すると 水酸化ナトリウム濃度が $1 \sim 2 \mathrm{~g} / 100 \mathrm{ml}$ のときエか゚キシ ドIが任意の濃度で 20３0 分後に界温し，东大水酸化 ナトリウムの濃度が $3 \mathrm{~g} / 100 \mathrm{ml}$ のときは20〜50 分後に は同浴処理液は $80 \sim 100^{\circ} \mathrm{C}$ に上昇する。これはエポキシ ドエの開環反坎，重合反庍がはげしく起るためと思われ る。したがって綿布をこれらの反度生成物と反応させる と反応熱か，汃なり影響して，絨維の内部に浸透して少 量の橋かけが奻果的な場所に起り，湿時しわ回復角は高 く得られるものと思われるが，逆に引裂強度保持率は低 下する。これらのことよりあらかじめポりマー形成を行 なった同浴パディング・タイミング処理の楊合と行なわ ないアルカリ前パディンダ・タイミング処理の場合とで は防しわ蚉果に若干の差違が認められることになると思 
われる。

同浴パディングのタイミング処理とスキーミング処理 を比较すると，湿時しわ回復角はタイミング処理より高 い值が得られたが，引致強度保持率ばスーーミング処理 のはらが，タイミング如理より大きい。このことはタイ ミング処理では，長時間膨潤状態で水酸化ナトリウムの

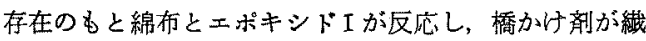
維の内部に充分澺して，湿時橋加け区広が效果的に起 るむのと思われるが，一部ポリマーの形成した反応生成 物が絵維表面に沈着するため綿布の硬さを增し，布の引 裂強度が低下するものと思われる。しかしスチーミング 処理では湿時しわ回復角はタイミング処理よりやゃ低 く、これは瀻維内部にポリマーと橋かけ剂の両方を固着 させることにより，引裂強度の低下がタイミング処理よ り改善されるるのと思われる。

塩基性触媒の存在のると乾燥状態での反応に打忊る樹 脂付着量, 乾時湿時しか回復角掞よびW \&W の効果は 同浴パディング・キュアリング処理>アルカリ後パディ ング・キュアリング娌理>アルカリ前パディング・キュ アリング处理の源となり，いずれの処理の場合も湿時〉 乾時のしわ回復角を示したが，酸性触媒の存在のもと乾 燥状態での反応帛のときより鼬時と乾時の両しわ回復角 は小さい值であった。これは乾燥状態での橋かけ反応が 起れば，当然非膨潤状態での橋かけ反応が起り，乾時し わ回復角が付与されるが，塩基性触媒は酸性触媒より乾 操状態での触媒効果は劣るため充分な橋かけ反応が起ら ないため，乾時のしわ回復角の向上が少ないためと思わ れる。また湿時しわ回復角の向上が少ないのは，橋かけ 反応の起こる温度に扎ける湿潤状態での反応時間が少な いためと想われる。これは同浴パディング・スチーミン グ処理に扎ける湿時しわ回復角が同浴パディング・キュ アリング処理上り高いことでもわかる。むた乾燥状態で 反応した場合の洗たえ 40 回後の樹脂脱落率は，湿濉状 態で反応したときのそれより大きく，洗たく40回後の W \& W は 2 となった。これは乾燥状熊での反応では壏 基性触媒の存在のbと綿布と二ポキシ化合物が反店する と，加水分解もるいはポリマーが形成され，一部未反応 エポキシ基が牫存しこれらが，洗たくによって脱落する ものと思われる。これは充分反応が進んでいると推察さ れる湿潤状熊で反応させた場合は樹脂脱落率が少なく， 洗たく 40 回後の W \&W 3 4 であることよりるお かる。またアルカリ後バディング・キュアリング好理を 再び $1 \%$ 水酸化ナトリウムでパディンダして 10 時間 のタイミング処理を行ならと湿時しわ回復角はアルカリ 後パディング・キュアリング怒理より向上し，しかも洗

* Derring-Milliken Research Corp. の商標
たく 40 回啳の樹脂脱落率が小さいことであわかる。

ウォシニアンドウェア加工に括いては湿時しわ回復 角が第一義的に考えられた 2 が，契用の点では乾時と湿 時の雨方の防しわ性が要求される。このため従来，满足 できる茈時しわ回復角を綿布に付与するためには湿潤橋 かけ反応の前（これを前樹脂加工と略記する）か，後 (これ後樹嘲工と略記する）に綿布を樹脂加工する ことが必要であるといわれた ${ }^{17,18)}$ 。.T.Marsh 5 ${ }^{19)}$ K 上れば，初期の Belfast* 加王2はジクロロプロパノ一 ルの湿式橋かけ反応で湿時しわ回復角を綿布に付与し， ついでアミノ采樹脂で樹脂加工して乾時しわ回復角を付 与していたが，これを逆に加工することにより耐久性の ある乾時と湿時の雨しわ回復伆が得られ，強度が改善さ れたと報告している。滝崎ら ${ }^{201} は$ はリアゾン澍脂で䄸布 を樹脂加工し，つぎに水酸化ナトリウムの存在のむのて エポキシ化合物の湿式処理を行ない、トリアジン樹脂自 体の酎酸性が増大することを報告している。

著者らは樹脂加工剂に DMDHEUを用いて，前樹脂加 工 (DMDHEU で樹脂加工した後, $\mathrm{NaOH}$-Epoxide 処 理) および後樹脂加工 ( $\mathrm{NaOH}-E$ poxide 処理後, DMDHEU で樹脂加工処理) を行なったところ, Table 4 K 示すように湿時しわ回復角性後樹脂加工>前樹脂加工の 順に大きく，執時しわ回復角および引裂強度について は，その逆になることがわかった。をた洗たく 40 回後 でもはぼ同様な傾向がみられたが，後樹脂加工は洗たく 回数が多くなる汪ど，樹脂付着量が少なくなり，乾時し わ回復角は前樹脂加工上り低下した。このことは，後樹 脂加工では，洗たく回数が増加するはど，樹脂が脱落す るためと思われる。すた前樹脂加工が洗たくた対し後樹 脂加工よりも高い乾時湿時しわ回復角之引裂強度の低下 の少ないことと，矿久性を示すのは，橋が忖分布が適切 に行なわれるためと思われる。前樹脂加工および後樹脂 加工の湿時しか回復角，W \& W 性は樹脂加工よりすぐ れた効果が認められた。

エポキシドエの濃度变化による処理方法がしか回復角 と引裂強度に及ばす影留は Fig. 3 に示すようにアルカ り前パディング・タイミング処理とアルカリ後パディン グ・タイミング処理を比校するとアルカリ前パディン グ・タイミング処理のほうが，湿時しわ回復解の问上が 著しい。これはエポキシトIの濃度が高くなると、エポ キシドIが繊維に唀し，ミクロフィブリル間の橋かけ 反応ばかりでなくラメラ間の橋か计反応が起る゙1ためと 思打れ岁。

乾時しわ回復角はアルカリ後パディング・タイミング 処理がルカリ前パディング・タイミング処理よりも高 い。これはアルカリ後パディング・タイミング処理でエ 
ポキシドIと綿布を反応するとき，エポキシドIを綿布 にメ゚ディングしたのb，予備乾燥の状態によって塩基珄 触媒の不存の漧燥状態で一部橋かけ反底が起り，このた め乾時しわ回復角が问上するるのと思われる。引裂強度 はアルカリ後パディング・タイミング処理〉アルカリ前 パディング・タイイング処理の順に低下が少なく、この

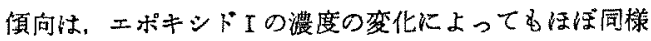
であった。

樹脂加工した綿布をアルカり前パディング・タイミン グ処理またはアルカリ後パディング・タイミンダ処理で 反応すれば，エポキシドの濃度が高くなるほど乾時と湿 時の両しわ回復角は向上し，逆に引㲎強度は低下した。 湿時しわ回復乍は樹脂加工一アルカリ前パディング・タ イミング処理>樹指加工゙ーアルカリ後パディング・タイ ミング処理の順に効果がすり，乾時しわ回復角和よび引 裂強度の低下はともにそれの逆となり，この傾向は土ポ

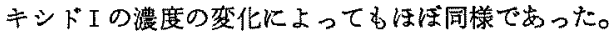

アルカリ前パディング・タイミング処理しなるのを樹 脂加工すると湿時しわ回復角は樹脂加工一アルカリ前パ ディング・タイミング処理するより高く得られるが，逆 に引列強度の低下は大さく，また㲦時しわ回復角は樹脂 加工ーアルカリ前パディング・タイミング処理するより 低かった。この㑯向は土ポキシドリの濃度の変化によっ てもは济同様であった。

3.4 アルカリ前バディング・タイミング処理および スチーミング処理における各種塩基性触媒の效果

各種塩基性触媒の存在のもとで綿布をアルカリ前パデ ィング・ダイミング処理拉よびスチーミング処理でエポ キシドIと反広したとき，樹脂付着盅としわ回復角の閣 係を Table 5 に示した。
湿時しか回復角に対しては Table 5 に示すようにタイ ミング処理ではメチルアルコラート〉水酸化ナトリウ ム〉過酸化ナトリウム>テトラメチルアンモニウムとド ロオキシド>イソブロピルアミンの順に効果があった。 前 4 者の間化は大な差はないが，特にメチルアルコラ 一ト ${ }^{229}$ は水酸化ナトリウムより效果のあることはアルコ ラートの膨潤能效果が寄与するためと思われる。

またスチーミング処理では過酸化ナトリウム二水酸化 ナトリウム>メチルアルコラートフテトラメチルアンモ ニウムヒドロオキシド>イソプロピルアミンの順に湿時 しわ回復角の向上に効果があった。過酸化ナトリウム28) は水酸化ナトリウムと同等の效果があるが，過酸化ナト リウムで反応するはらが水酸化ナトリウムで反応するよ り綿布はやや白く仕上った。これは発生機の酸素による 酸化作用で綿布に付着している不純物が漂白されるため と思われる。アルカリ前パディング・タイミング処理で のテトラメキルアンモニウムヒドロオキシド2)は水酸化 ナトリウムとほぼ同程度の湿時しわ回復角が得られた。 イソプロピルアミンをるらいた場合では樹脂付着量快他 の触媒をもらいた場合より大きいにすかかわらず，湿時 しわ回復角の向上はタイミング処理およびスチーミング 処理いずれの場合にも得られなかった。これは橋かけ反 応にあづからないでポリマーが形成したためと思われ る。したがってインプロピルアミンは橋かけ触媒として は不適当であることがわかる。

各種塩基性触桇を用いてタイミング処理およびスチー ミング処理をおこなった場合，湿時しわ回復角はスチ一 ミング処理では 3 分の反応で高い湿時しわ回復角が得ら れたが，同程度の湿時しわ回復角はタイミング処理の反 応では的 10 時間必要であった。スキーミング処理で反

Table 5. "Timing" or "Steaming" Treatment of Cotton Fabrics with Epoxide I in the Presence of Various Alkaline Catalysts.

\begin{tabular}{|c|c|c|c|c|c|c|}
\hline \multirow{3}{*}{ Catalyst } & \multicolumn{3}{|c|}{ Timing treatment } & \multicolumn{3}{|c|}{ Steaming treatment } \\
\hline & \multirow{2}{*}{$\begin{array}{c}\text { Resin } \\
\text { add-on } \\
\%\end{array}$} & \multicolumn{2}{|c|}{$\begin{array}{l}\text { Wrinkle recovery } \\
\text { ang. }(W+F) \text { deg. }\end{array}$} & \multirow{2}{*}{$\begin{array}{c}\text { Resin } \\
\text { add-on } \\
\%\end{array}$} & \multicolumn{2}{|c|}{$\begin{array}{l}\text { Wrinkle recovery } \\
\text { ang. }(W+F) \text { deg. }\end{array}$} \\
\hline & & Dry & Wet & & Dry & Wet \\
\hline Sodium hydroxide & 5.6 & 185 & 296 & 3.5 & 190 & 296 \\
\hline Sodium peroxide & 5.0 & 188 & 295 & 3.5 & 193 & 296 \\
\hline Sodium methylate & 5.5 & 180 & 298 & 3.8 & 185 & 293 \\
\hline Tetramethyl ammonium hydroxide & 4.5 & 195 & 294 & 3.0 & 180 & 294 \\
\hline Isopropyl amine & 6.5 & 223 & 246 & 4.3 & 218 & 245 \\
\hline Control fabric & 0 & 177 & 200 & 0 & 177 & 200 \\
\hline
\end{tabular}

Reaction condition: The cotton fabric was padded with various alkaline catalyst $(3 \mathrm{~g} / 100 \mathrm{~m} l$, wet pickup, $70 \%)$, followed by padding with Epoxide $1(30 \mathrm{~g} / 100 \mathrm{ml}$, wet pick-up, $70 \%)$. The impregnated fabric was allowed to react by the timing process at $25^{\circ} \mathrm{C}$ for $10 \mathrm{hr}$. or the impregnated fabric was treated by steaming at $100^{\circ} \mathrm{C}$ for $3 \mathrm{~min}$. The treated fabric was soaped as described in Table 1 . 
Table 6. "Timing" or "Steming" Treatment of Cotton Fabrics with Various Solvents of Epoxide I in the Presence of Sodium Hydroxide.

\begin{tabular}{|c|c|c|c|c|c|c|c|}
\hline \multirow{3}{*}{ Solvent } & \multirow{3}{*}{ Mol. wt. } & \multicolumn{3}{|c|}{ Timing treatment } & \multicolumn{3}{|c|}{ Steaming treatment } \\
\hline & & \multirow{2}{*}{$\begin{array}{c}\text { Resin } \\
\text { add-on } \\
\%\end{array}$} & \multicolumn{2}{|c|}{$\begin{array}{l}\text { Wrinkle recovery } \\
\text { ang. }(W+F) \text { deg. }\end{array}$} & \multirow{2}{*}{$\begin{array}{c}\text { Resin } \\
\text { add-on } \\
\%\end{array}$} & \multicolumn{2}{|c|}{$\begin{array}{l}\text { Wrinkle recovery } \\
\text { ang. }(W+F) \text { deg }\end{array}$} \\
\hline & & & Dry & Wet & & Dry & Wet \\
\hline Benzene & 78 & 2.8 & 182 & 270 & 1.3 & 185 & 263 \\
\hline Tetrahydrofuran & 72 & 3.1 & 185 & 276 & 1.8 & 188 & 270 \\
\hline Dioxane & 88 & 3.7 & 192 & 280 & 2.0 & 190 & 276 \\
\hline Acetone & 58 & 4.0 & 190 & 285 & 2.3 & 195 & 280 \\
\hline Isopropyl alcohol & 60 & 4.3 & 185 & 288 & 2.6 & 190 & 285 \\
\hline Ethyl alcohol & 46 & 4.5 & 180 & 290 & 3.0 & 181 & 286 \\
\hline Methyl alcohol & 32 & 4.8 & 183 & 293 & 3.3 & 187 & 288 \\
\hline Isopropyl alcohol + water (1:1) & & 5.0 & 188 & 295 & 3.5 & 192 & 290 \\
\hline Ethyl alcohol+water $(1: 1)$ & 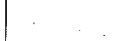 & 5.1 & 185 & 297 & 3.4 & 183 & 292 \\
\hline Metyl alcohol + water $(1: 1)$ & & 5.2 & 190 & 297 & 3.6 & 185 & 294 \\
\hline Water & 18 & 5.2 & 190 & 305 & 3.8 & 188 & 295 \\
\hline Control fabric & & 0 & 177 & 200 & 0 & 177 & 200 \\
\hline
\end{tabular}

Reaction condition: The cotton fabric was padded with sodium hydroxide (wet pick-up, 70\%), followed by padding with Epoxide I ( $30 \mathrm{~g} / 100 \mathrm{~m} l$, wet pick-up, $70 \%$ ) in various solvents. The impregnated fabric was allowed to react by the timing process at $25^{\circ} \mathrm{C}$ for 10 hours or the impregnated fabric was treated by steaming at $100^{\circ} \mathrm{C}$ for $3 \mathrm{~min}$. The treated fabric was soaped as described in Table 1 .

㐫すれば短時間で高い湿時しわ回復角が得られるのは織 維が充分膨潤し橋かけ反応が早く起るためと思われる。

\section{5 各種溶媒の効果}

水酸化ナトリウムの存在のもとでェポキシドI（水溶 液またはジオキサン溶液）と綿布をアルカリ前パディン グ・タイミング処理で反応するとき，反応時間がしか回 復角と樹脂付着量に拉よほす影響を Fig. 4 に示した。 重た水酸化ナトリウムの存在の女とで各種溶媒にとかし たエポキシド1と綿析をアルカリ前パディグ・タイミン グ処理かるいはスチーミング処理で反応させたときの樹 脂付着量としわ回復角の関係を Table 6 K示した。

亟性々親水性の影響をるつ溶剂が䋘維に対してどの程 度の膨潤をあたえるかを，湿時しか回復角の向上上りみ るためますジオキサンで線布を㛆理した。Fig.4亿示す よ5に反応温度が $20^{\circ} \mathrm{C}$ より $60^{\circ} \mathrm{C}$ 高くなるにしたがっ て高い湿時しわ回復角が得られたが，湿時しわ回復角 は，反応温度と時䦎により相違を示した。

水溶液では Fig.4-1 に示すように $20^{\circ} \mathrm{C}$ のと反度 時間 10 時間付近まで急激に鼬時しわ回復传惊くなる が，その後は漸増し 18 時間付近でほほ館和点に達し， 樹脂付着量は $5.8 \%$ になった。 $40^{\circ} \mathrm{C} て ゙ は 6$ 時間付近ま で急增するが，その後濑增し，12時間付近でほぼ飽和点 に達し，橋脂付着量は $6.2 \%$ となった。 $60^{\circ} \mathrm{C} て ゙ は 6$ 時 間付近まで急増し，その後漸增し，9時間村近で，ほぼ
飽和点火達し，樹脂付着量は6.1\%になった。100 C で は4時間付近まで急增し，その後漸増し，6時間付近で ほぼ飽和点に達し，樹脂付着量は6.7\%になった。した がって低温仼ど長い反庆時間で高い湿時しわ回復角が得 られ，高温になるほど短い反応時間で高い湿時しわ回復 角が得られる。このことは反応温度は湿時しわ回復角火 非常に影锦を与えることを意味している。

ジオキサンの場合はに Fig. 4-2 示吉よ5に, Fig. 4-1 々㭱济京様な向を示した。このことは水、ジォキサンい ずれの溶媒で毛温度が高くなるはど緎維が膨潤し，この

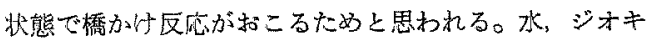
サンを比較すると，水を用いたほらがジオキサンの場合 より高い湿時しわ回復が得られた。これは水のほうが緎 䧽に対して大きい膨閏をあたえるためと思われる。

また各種溶媒の湿時しわ回復角比対する效果は Table 6 に示方ようにタイミング処理，スキーミング処理とも に水〉メタノール>エタノール>イソプロピルアルコー ル〉アせトン>ジオキサン>テトラヒドロフラン>ベン ゼンの順となった。この結果植性の大きい溶媒任ど効果 は大きい。これは溶媒による渗透能の差に関連するるの と思われ，我溶液や低悢アルコールほど綿布に対する竸 潤能が大になり，橋か计剂が縄維の内部まで渗透して橋 かけ区広を起し，この結果湿時しわ回復角は向上すると 考えることができる。この考察は上にのべた樹脂付着量 


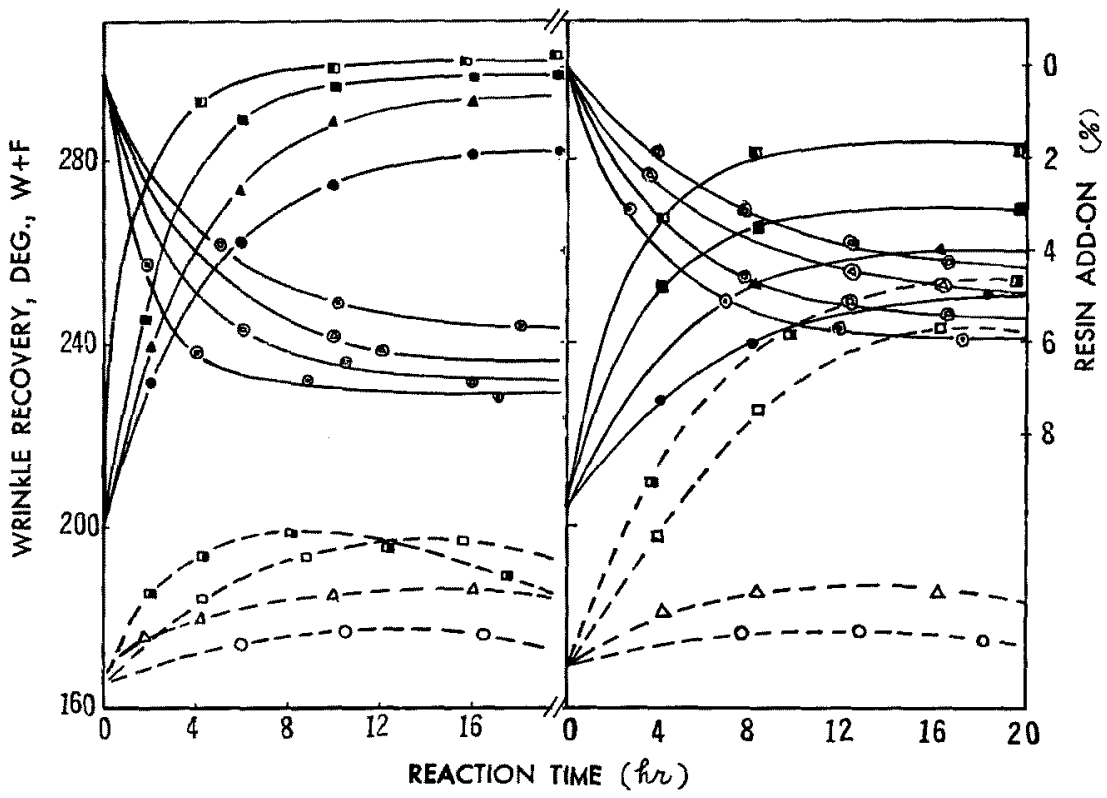

Fig. 3-1. Solvent (water)

Fig. 4-2. Solvent (Dioxane)

Fig. 4. The effects of reaction time on the wrinkle recovery angles and resin add-on when cotton fabrics were treated with Epoxide I dissolved in various solvents in the presence of sodium hydroxide.

Reaction condition: The cotton fabric was padded with sodium hydroxide $(3 \mathrm{~g} / 100 \mathrm{ml}$, wet pick-up, $70 \%)$, followed by padding with Epoxide I $(20 \mathrm{~g} / 100 \mathrm{ml}$, wet pick-up, 70\%). The impregnated fabric was allowed to react by the wet timing process at $20,40,60$ or $100^{\circ} \mathrm{C}$.

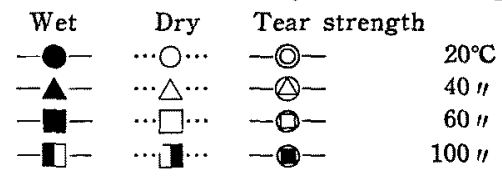

の増加からもららづけられる。

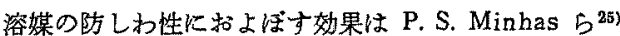
が種々の溶媒で膨潤させた状態沈けりるアクセシビリテ 1を求めた結果とほぼ一致した。また紻維の膨潤に水の 存在が大きく影響することもわかった。

乾時しわ回復角は Fig. 4-1 に示すように温度が高く なってむ向上はみられないが，Fig. 4-2 では反応温度が $60^{\circ} \mathrm{C}$ 以上で反底時間が長い注之乾時しわ回復角は向上寸 ることがかかった。これはこの温度で溶媒が蒸発し，こ

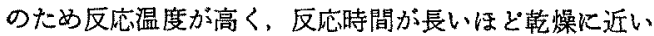
状態で憍かけ反応が起り，この結果乾時しわ回復角が向 上するものと思加る。

\section{4. 総括}

以上の実験結果から次のことがい光る。

1. 水酸化ナトリウムの存在のもとで各種エポキシド
と綿布をアルカリ前パディング・タイミング処理で反応 すると

（1）湿時しわ回復角は樹脂付着量が増加するほど高 くなり，その効果はエポキシド $\mathrm{I}>\mathrm{III} 〉 \mathrm{II}>\mathrm{V}$ の順とな ったが，引裂強度はその逆の関保になった。湿潤状㦔で の橋かけ反応では乾時しわ回復角火得られなかった。

（2）エポキシドI，林ともに湿時しわ回復角は反応 温度と塩基性䖵媒濃度によって相違を示し，触媒濃度が 高いはど硬く仕上った。

2. エポキシドエ，低をアルカリ前パディングス・ス チーミング処理で反応すると，湿時しわ回復角は樹脂付 着量が $3 \sim 4 \%$ で急激に向上し，それ以上の付着量では 激增した。樹脂加工布のそれは樹脂付着量が $6 \sim 7 \%$ 付 近で急激に向上し，それ以上の付着量では漸增した。

3. 湿潤状態での反応はアルカリ前パディング・タイ ミング処理, アルカリ後パディング・タイミング処理拉 
上びスチーミング処理，同浴パディング・タイミング処 理执よびスチーミング処理のいずれの場合でる湿時>乾 時のしわ回復角を示した。

4. 湿潤状態の反応化和ける樹脂付着量, 湿時しわ回 復角批よび W \& W の効果は同浴パディング・タイミン グ処理〉アルカリ前パディグ・タイミング処理〉同浴パ ディング・スチーミング処理〉アルカリ後パディング・ タイミング処理〉アルカリ後パディング・スキーミング 処理の順となったが，乾時しか回復角は忹とんど得られ なかった。引裂強底保持率は樹脂付着量, 湿時しわ回復 角就よび W \&W の效果の大きいほど小さく，それと逆 の関係寺し，剛軟度はとれらの効果が大きい经ど大き い值を示した。これらの傾向は洗たく 40 回後でるほほ 同様であった。

5. 乾燥状態での反応における樹脂付着量, 乾時湿時 しわ回復角拉よび W \& W の効果は同浴パディング・キ ニアリング処理>アルカリ後パディング・キュアリング 処理>アルカリ前パディング・キュアリング処理の順と なり，そのいずれの処理の場合であ湿時>乾時のしか回 復角を示した引列强度保持率は樹脂付着量, 乾時湿時し わ回復角および W \& W の効果の大きい棌ど小さく，そ れと逆の関保を示した。洗たく 40 回後でるほぼ同様な 傾向を示したが，洗たく 40 回後の樹脂脱落率は湿潤状 態での反応より大きかっだ。乾爆状態での反応したもの を，さらに湿潤状態で反応すれば湿時しわ回復角が翰燥 状態での反応のときより向上した。

6. 前樹脂加工と後樹脂加工を比較すると，湿時しか 回復角の効果性前樹脂加工く後樹脂加工の順となり, 前 樹脂加工，後樹脂加工ともに樹脂加工上りすぐれた效果 が認められた。また前樹脂加工，後樹脂加工の乾時しわ 回復角战よび弓晊強度の低下は前樹脂加工>徭樹脂加工 の順となり，乾時しわ回復角は樹脂加工とほぼ同じょう な値を示したが，引裂强度の低下は樹脂加工がその両者 より少なかった。

7. 各種の塩基性触媒に上る湿時しわ回復角の効果 は, アルカリ前パディング・タイミング処理ではメチル アルコラート〉水酸化ナトリウム〉過酸化ナトりウム> テトラメチルアンモニウムヒドロオキシド>イップロピ ルアミンの順となり，アルカリ前パディング・スチーミ ング処理では, 過酸化ナトリウム二水酸化ナトリウム> メチルアルコラート〉テトラメチルアンモニウムヒドロ オキシド>イップロピルアミンの順となった。

8. 各種の溶媒による湿時しわ回復角の効果は, アル カリ前パディング・タイミング処理怙よびアルカリ前ハ ディング・スチーミング処理ともに水〉メタノール>エ タフール>イソプロピルアルコール>アセトン>ジオキ
サン>テトラヒドロフランフベンゼンの順となった。乾 時しわ回復角恃反応温度が $60^{\circ} \mathrm{C}$ 以上で反応時閒が長い はど向上する傾向がみられた。

付 記

本研究の発表を許可された日清絖續株式会社，ならび 飞常務取締役岡田稳工務本部長招よび田中幸一美合工場 長に㳭甚なる謝意を表する。またご指導を賜った美合工 場林忠男研究所課長に感謝の意を表する。

文献

1) B. J. Brown, L. Steger (to Forthergill and Harvey, Ltd.) B. P. 695,282 (1953. 8. 26 : Gf G.C. Mussel, Ind. Textile., 69, 103 (1952)

2) Deering-Milliken Research Corp., B. P. 855,547 (1960); Deering-Milliken Research Corp., U. S. P. 2, 985, 501 (May 23. 1961)； 特公昭 345250

3) J. B. McKelvey, R. R. Benerite, R. J. Berni and B. G. Burgis ; J. Applied Poly. Sci., 7, 1371 (1963)

4) J. B. Mckelvey, R. R. Benerito, R. J. Berni and C. A. Hattox; Textile Res. J., 34, 759 (1964)

5) J. T.Marsh ; Textile Manuf., 93, 25 (1967)

6) J. B. Mckelvey, B.G.Webre, E. Klein ; Textile. Res. J., 29, 918 (1959)

7) E. W. Jones, J. A. Rayburn ; J. Applied Poly. Sci., 5, 714 (1961)

8) J. B. Mckelvey, R. R. Benerito, B. G. Webre, R. J. Berni ; J. Polymer Sci., 51, 209 (1961)

9) H. M. Ziifle, R. R. Benerito, R. J. Berni, A. M. Cannizzoro; Textile Res. J., 38, 1101 (1968)

10）本宮蕫也；载学誌，25，502（1969）

11）寺田仁計, 根本嘉郎；，名市工研報，No. $35 ， 22$ (1996)

12) JIS L 1004-1959

13）本宮達也，中攧博文（日清紡）；特公昭 39-12098

14) B. P. 704,143 (1954)

15）小西行婎, 田中隆吉, 吉武春男, 林 茂助, 三井 忠直; 日本綿業技術研究所, 研究報告, No. 43, 25 (昭和 35 年)

16) T. Francis and M.L. Staples ; Textile Res. J., 33, 583 (1963)

17) S. P. Young; Textile Industries, July, 113 (1961)

18) F. Nestelberger ; Melliand Textil-Berichte, 43, 504 (1962)

19) J. T. Marsh ; Textile Manuf., 90, 197 (1964)

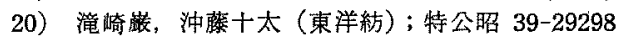

21) W. A. Reeves, R. M. Kullman, J. G. Frick, Jr., R. M. Reinhardt ; Textile Res. J., 33, 169 (1963)

22）本宫達也（日清紡）；特公昭 39-7747

23）本宮達也, 海野说次郎(日清紡)；特公昭 39-27020

24）本宫達也，野村達男（日清紡）；特願昭 42-78525

25) P. S. Minhas, A. A. Robertson; Textile Res. J., 37, 400 (1967) 